\title{
COMMENTARIES
}

James A.R. Nafziger ${ }^{*}$

nafzige@willamette.edu

Willamette University College of Law

245 Winter Street SE

Salem, Oregon 97301

United States

\section{Trading and Returning Cultural Objects under International Law}

\begin{abstract}
This paper discusses the European Directive 2014/60 within a broader regime of international law applicable to claims for the return by states of cultural objects that have been unlawfully removed from the territory of other states. The foundation of this regime is international trade law, based on national import and export controls within a framework established by the 1994 GATT. Claims for the return (and restitution) of objects, after the fact of an international transfer, are based on national laws of cultural patrimony and provisions of international instruments, primarily the 1970 UNESCO and 1995 UNIDROIT Conventions. International human rights law is also important. Article XI of the 1994 GATT, which prohibits quantitative restrictions on the import and export of goods, would appear to inhibit national controls over trade in cultural objects. But the prohibition is subject to an exception in Article XX for measures imposed on the protection of national treasures of artistic, historic or archaeological value. This exception is reiterated
\end{abstract}

\footnotetext{
* James A.R. Nafziger (B.A., M.A., University of Wisconsin; J.D., Harvard University) is the Thomas B. Stoel Professor of Law and Director of International Programs at the Willamette University College of Law (USA). He is also Honorary Professor at the East China University of Politics and Law. A former Administrative Director of the American Society of International Law, of which he is currently Secretary, he has been a Fulbright lecturer in Mexico and Mongolia as well as Scholar - in Residence at the Rockefeller Foundation's Study Center in Bellagio, Italy. His numerous cutting-edge articles and five books on cultural heritage issues, include a volume of The Hague Academy of International Law where he served as Co-Director of Research in 2005. He chairs the Committee on Cultural Heritage Law of the International Law Association and is a member of its Executive Council, as well as Honorary Vice-President of the I.L.A.'s American Branch, having served as President and Chair of its Executive Committee. He is an elected member of the American Law Institute.
} 


\section{COMMENTARIES}

James A.R. Nafziger

in Article 36 of the TFEU and Directive 2014/60. It will be apparent that private international law necessarily plays a significant role in governing the transnational movement and return of cultural objects. National export and import laws that pertain to cultural objects vary from non-existent or neglected to highly restrictive and effective. The scope of national compliance with the international regime governing the restitution and return of objects and the requirements of the national administrative processes involved also vary widely. In all, legal pluralism flourishes unsurprisingly, given the complexity of the international regime, inevitable discrepancies among its components, and the multiplicity of actors and political currents in the process of cooperation.

Keywords: international trade, cultural exception, national treasures, return of cultural objects, compliance with international obligations

\section{Introduction}

It is a genuine pleasure and honour to have this opportunity to keynote what promises to be a highly informative and productive conference on Directive 2014/60/EU on the return of cultural objects. ${ }^{1}$ I know that I will learn a lot from all of you.

As an American addressing the broad topic of "Trading and Returning Cultural Objects under International Law," I am certainly an outlier. Unlike most of you, I cannot offer insights drawn from experience within the European system. Also, I am from the only major country and legal system with no specific controls over the export of cultural objects other than those originating on federal or Native American lands - and even then, only indirectly. Moreover, American jurisprudence is fundamentally hostile to the enforcement of foreign export laws. Accordingly, the range of "unlawfully removed" objects that are subject to "return," in the words of the Directive, is rather limited. Finally, from a non-European perspective, the hybrid or blend of constitutional and international dimensions in the European Union (EU) regime is always a challenge for us Americans.

Let me, however, attempt to set the stage for this conference. Perhaps my transatlantic perspective can offer some new insights. In any event, I was asked simply to describe the international law that supports Directive 2014/60/EU so as to establish a common understanding for all of us - practicing lawyers, officials

1 Directive 2014/60/EU of the European Parliament and of the Council of 15 May 2014 on the return of cultural objects unlawfully removed from the territory of a Member State and amending Regulation (EU) No. 1024/2012, OJ L 159, 28.05.2014, p. 1. 
of governments and international organizations, academic experts, and students. I will then suggest some strengths and weaknesses of this body of law, particularly the 1970 UNESCO Convention against illegal trafficking in cultural property (1970 UNESCO Convention), ${ }^{2}$ and conclude with a few observations about national initiatives and variations among them. In the time I have for my remarks, I am going to rely disproportionately on examples from the United States and on trading issues concerning archaeological objects.

Three treaties form a sort of tripod of authority to support the platform of the EU Directive and other specialised instruments to protect cultural heritage. This tripod includes the General Agreement on Tariffs and Trade 1994 (GATT 1994), ${ }^{3}$ the 1970 UNESCO Convention and the 1995 UNIDROIT Convention on Stolen or Illegally Exported Cultural Objects (1995 UNIDROIT Convention). ${ }^{4}$ These instruments support the EU Directive, but differ from it in some ways. For example, although the concept of national treasures in the EU Directive is drawn from GATT 1994, it departs from the concept of "cultural property" embedded in the other two treaties. Also, the relationship between national treasures and the concept of cultural patrimony in the two treaties merits examination and clarification. Other differences between the Directive and the three instruments will be discussed later in this commentary.

\section{GATT 1994}

GATT 1994, as part of the Agreement Establishing the World Trade Organization (WTO), ${ }^{5}$ has 162 members or States Parties. For our present purposes, Article XI of GATT 1994 is fundamental. It prohibits quantitative restrictions - sometimes called "quotas" - on both the import and export of goods. Import restrictions are typically more extensive than export restrictions, as they are customarily applied to protect a vocal constituency of domestic producers from imports of what are often pejoratively described as "cheap foreign goods." Export restrictions, however, are typically employed for the less sensitive public purposes of protecting limited supplies of locally-produced goods, national security or protection of the general well-being, which includes cultural well-being and identity. Another important difference between import and export controls is that export controls are usually harder to enforce since border control stations customarily focus on collecting duties or enforcing health, safety, and other concerns related to imports.

\footnotetext{
2 UNESCO Convention on the Protection and Promotion of the Diversity of Cultural Expressions, 20 October 2005, 2440 UNTS 311.

3 General Agreement on Tariffs and Trade 1994, 1867 UNTS 154, 33 ILM 1154 (1994), with reference to the original document, General Agreements on Tariffs and Trade, 30 October 1947, 55 UNTS 194.

4 Final Act of the Diplomatic Conference for the Adoption of the Draft UNIDROIT Convention on the International Return of Stolen or Illegally Exported Cultural Objects, 24 June 1995, 34 ILM 1322 (1995).

5 Agreement Establishing the World Trade Organization, 15 April 1994, 1867 UNTS 3.
} 


\section{COMMENTARIES}

James A.R. Nafziger

Among the exceptions to the prohibition of restrictions on trade in Article XI, however, is Article XX, which allows national measures that are "imposed for the protection of national treasures of artistic, historic or archaeological value". Article 36 of the (Lisbon) Treaty on the Functioning of the European Union ${ }^{6}$ is similarly worded. The precise scope of the term "national treasures" remains unclear, however. It has never been the subject of analysis by a GATT or WTO panel or by the WTO Appellate Body. Indeed, Article XX is sort of a legal Lohengrin. Nobody is entirely sure where it came from in the absence of any clues in the travaux preparatoires of GATT.7 Nor, as in the legend of Lohengrin, do we know exactly where the term then disappeared within the realm of international law. So, the authority to define a national treasure seems to be vested securely in national legal systems.

The selection and degree of specificity of national treasures is not always easy to determine. Some of you may have seen, as I did yesterday, a delightful exhibit entitled "Anything Goes" at the National Museum here in Warsaw. It was assembled by a group of apparently precocious 6-14 year-old children. In particular, one section of the exhibit, entitled "treasure trove" attracted my attention. According to a description on the wall, the children had a particularly difficult time deciding what were the most worthy treasures. "We each had a different favorite," they explained. If the selection of the most treasured of the treasures was difficult for 6-14 year-olds, all the more so for adult experts! Moreover, maybe the children had something to teach adults insofar as the treasure trove they ultimately selected was highly internationalistic - in effect, a common heritage of humankind - with surprisingly few objects from Poland. And so, as we move on from this brief look at GATT 1994, we might ask how this unstudied concept of a common heritage might bear on claims for the return of cultural material to countries of origin within Europe.

\section{The 1970 UNESCO Convention}

The second leg of the tripod of primary international legal authority concerning cultural heritage is the 1970 UNESCO Convention. It has 131 States Parties, including virtually all of the major art-market States. Even though its overall relationship to international trade law remains somewhat imprecise, it is the most important international agreement for cooperation in deterring and responding to illegal trafficking in cultural objects. Sadly, such trafficking is the third most lucrative, after drugs and arms, amounting to as much as an estimated six billion dollars

\footnotetext{
6 Consolidated version, OJ C 326, 26.10.2012, p. 47.

7 The term "national treasures" may have been borrowed from prior commercial and trade agreements. See C. Wilcox, A Charter for World Trade, Macmillan, New York 1949, p. 180. On GATT 1994 as it pertains to cultural objects, see generally T. Voon, Cultural Products and the World Trade Organization, Cambridge University Press, Cambridge 2007.
} 
each year. Just as sadly, the estimated recovery rate of illegally trafficked material is a dismal $2 \%$ or $6 \% .^{8}$

A singular achievement of the 1970 UNESCO Convention was the first detailed definition of the term "cultural property". Accordingly, it is "property, which on religious or secular grounds, is specifically designated by each State as being of importance for archaeology, prehistory, history, literature, art or science" 9 and which falls within any of the eleven enumerated categories.

The 1970 UNESCO Convention's most important provisions are as follows: a system of mutually enforceable export certifications by each State Party; emergency measures for parties to call on each other to prohibit the importation of a specified class or classes of cultural property that are in jeopardy as a result of international trafficking; a requirement that parties return property within their jurisdiction stolen from museums, monuments, and other institutions; a requirement that, "consistent with national legislation", parties prevent museums and similar institutions from acquiring property illegally exported from other states; a commitment that parties impose penalties or other administrative sanctions for stipulated violations of the treaty; and a provision for international cooperation in identifying cultural property and developing national inventories. Contraband items are recoverable on demand by the state of origin, so long as just compensation is paid to innocent purchasers. Overall, the Convention strikes a compromise between the interests of art-importing and art-exporting states while requiring the importing state's cooperation in the recovery and retrieval of illicitly exported property.

\section{The 1995 UNIDROIT Convention}

The third leg of the tripod of primary legal authority is the 1995 UNIDROIT Convention, with 37 States Parties. Its aim was to strengthen the regime established by the 1970 UNESCO Convention by filling gaps that had become apparent in it, particularly involving questions of procedural and private law such as those related to statutes of limitations and the bona-fide purchaser. The Convention uses the term "cultural objects", which tracks the definition of "cultural property" in Article 1 of the 1970 UNESCO Convention. As with the UNESCO Convention, the 1995 UNIDROIT Convention only applies prospectively. It therefore does not apply to objects stolen or smuggled into the territory of a State Party before the Convention comes into force in that State.

Chapter II of the 1995 UNIDROIT Convention concerns the restitution of stolen cultural objects. Under Article 3, the term "stolen cultural object" is expanded to include objects unlawfully excavated or lawfully excavated but unlawfully re-

8 P. Pobric, US Fails to Tackle Art Crime, "Art Newspaper", April 2013, p. 5. The estimates are, however, uncertain if not speculative.

91970 Convention, op. cit., Article 1. 


\section{COMMENTARIES}

James A.R. Nafziger

tained, consistent with the law of the State where the excavation took place. Claims for restitution of such objects must be made within three years after the claimant actually discovers where the object is located and who possesses it. Also, all claims must be made within fifty years from the time of the theft. However, this rule of repose does not apply to objects belonging to public collections, forming part of identified monuments or archaeological sites, or sacred and communally important objects belonging to tribes or other indigenous groups. A party to the Convention can declare, however, that a claim is subject to a generous time limitation of seventy-five years or longer under its law.

Persons required to restitute stolen cultural objects are entitled to fair and reasonable compensation so long as they are unaware or ought not to have been aware that an object was stolen and have exercised due diligence when acquiring such an object. Article 4(4) identifies factors that apply to the determination of whether the requirement of due diligence has been satisfied, such as the price paid, whether the possessor consulted any accessible register of stolen objects, and simply "the character of the parties".

Chapter III of the Convention concerns the return of illegally exported cultural objects. Such objects must be returned on the request of a State Party to the courts or other competent authority of another State Party. Article 5(3) provides that such a court or other competent authority shall order the return of an object illegally exported if the requesting State establishes that the removal of the object from its territory "significantly impairs" one or more of several interests. This qualification was an important concession to art market states reluctant to recognize source state export controls regardless of their scope or consequences. Chapter III also includes a statute of limitations and repose provision similar to those under Chapter II concerning the restitution of stolen objects as well as a distinctive provision for compensation of a possessor. Another paragraph provides for agreements between the requesting state and the possessor of an object that may specify either the possessor's retention of an object or its transfer either for payment or ex gracia to a specifically defined person of the possessor's choice.

\section{Other instruments of international law}

These three instruments, then, constitute the tripod of primary international legal authority to support a platform for Directive 2014/60/EU and other measures of international and regional cooperation, as well as national laws, for restituting and returning stolen and illegally exported cultural objects, respectively. At the regional level, other EU measures, particularly Council Regulation 116/2009 on the external export of cultural objects outside the $\mathrm{EU}^{10}$ are of course important. But

10 Codified version, OJ L 39, 10.02.2009, p. 1. 
there is much more to the platform of cooperation in the form of other multilateral and bilateral agreements. To take just one multilateral example, the 2001 UNESCO Convention on the Protection of the Underwater Cultural Heritage ${ }^{11}$ requires its 54 States Parties to seize and properly dispose of heritage recovered from historic shipwrecks and cargo in violation of the Convention and to impose effective sanctions for such violations.

Soft law can also strengthen the regime. For example, the Principles for Cooperation in the Mutual Protection and Transfer of Cultural Material, ${ }^{12}$ which was adopted by the International Law Association in 2006, helps define good stewardship for the caring and sharing of cultural heritage. The instrument's Preamble emphasizes the need for a guiding spirit of partnership among private and public actors through international cooperation, and is intended to be used by a broad range of interested parties, governments, museums, other institutions, individual persons and groups of persons. The Principles cover eight topics: (1) requests and responses to requests for the transfer of cultural material; (2) alternatives to the transfer of cultural material; (3) cultural material of indigenous peoples and cultural minorities; (4) human remains; (5) requests for return or restitution of cultural material; (6) notification of newly found cultural material; (7) considerations for effective negotiations concerning requests; and (8) dispute settlement.

In helping resolve such disputes, UNESCO's Intergovernmental Committee for Promoting the Return of Property to its Countries of Origin or its Restitution in Cases of Illicit Appropriation, despite its unwieldy name, offers a variety of readily acceptable services, including mediation and conciliation facilities. ${ }^{13}$

\section{The stability of the tripod of treaties}

Let me now return to the tripod of treaties and its stability. As we know, tripods are not always stable. With respect to GATT 1994, as I mentioned earlier, its national-treasure exception to quantitative export controls appears mysteriously and then promptly disappears like Lohengrin with little or no formal jurisprudence or guidance by the WTO. As to the 1995 UNIDROIT Convention, I will gratefully defer

\footnotetext{
112 November 2001, 41 ILM 40 (2002).

12 Principles for Cooperation in the Mutual Protection and Transfer of Cultural Material, International Law Association, Report of the Seventy-Second Conference 2006, p. 338; see J.A.R. Nafziger, The Principles for Cooperation in the Mutual Protection and Transfer of Cultural Material, "Chicago Journal of International Law" 2007, Vol. 8, p. 159.

13 The Intergovernmental Committee was entrusted with the task of promoting bilateral agreements for the return or restitution of cultural property. Originally it focused mostly on issues resulting from colonization and military occupation, but today, in the post-colonial era, it has a much broader scope. The Committee seeks to assist countries in building representative collections of cultural material, to prepare national inventories, to inform public opinion, to help develop museum personnel, to facilitate international exchange, and to advise UNESCO on pertinent issues. See A.F. Vrdoljak, International Law, Museums and the Return of Cultural Objects, Cambridge University Press, Cambridge 2006, p. 213, 234.
} 


\section{COMMENTARIES}

James A.R. Nafziger

to Marina Schneider's expertise for further commentary. That leaves us with the 1970 UNESCO Convention, on which I will now focus the remainder of my remarks.

\section{Ambiguous terminology}

In the words of Lyndel Prott, the former Director of UNESCO's Division of Cultural Heritage, "[t]he drafting of the 1970 convention is not entirely satisfactory and has given rise to divergent interpretations" ${ }^{14}$ I agree. Let me offer my own specific observations, first, on the operational language and then on a broader assessment of the Convention's strengths and weaknesses. I have time to cite just three ambiguities in the language of the Convention. ${ }^{15}$ Let us begin with Article 4, which defines the term "cultural heritage" to include, among other material, that which is "found within the national territory". The phrase "found within" has been interpreted variously to include, on the one hand, undiscovered material that may be found in the future but has not yet been actually discovered, and, on the other hand, only material that has been actually found in the sense of having been discovered or having otherwise specifically come to light. ${ }^{16}$

There is certainly room for compromise and eventual consensus in clarifying the language of Article 4. For example, United States' courts have adopted the common law requirement of possession in order to vest property ownership. This might seem to bar ownership claims by other States Parties to undiscovered material. But the common law requirement of actual possession is subject to a recognition of national antiquities laws and judicial decisions that either expressly vest the ownership of cultural material in the State or imply a delivery of it into possession of the State without any requirement of ${ }^{17}$ actual discovery of the material under Article 4. Nor does Article 9 of the 1970 UNESCO Convention, which provides for mutual cooperation in prohibiting the importation of certain classes of material important to a cultural patrimony and in jeopardy, contain any requirement of actual discovery at the level of international cooperation except in terms of broad categories of objects. A federal appeals court in the United States has in effect confirmed this interpretation in Ancient Coin Collectors Guild v. U.S. Customs and Border Protec-

14 L.V. Prott, UNESCO International Framework for the Protection of the Cultural Heritage, in: J.A.R. Nafziger, A.M. Nicgorski (eds.), Cultural Heritage Issues: The Legacy of Conquest, Colonization and Commerce, Martinus Nijhoff Publishers, Leiden 2009, p. 257, 265.

15 The discussion that follows is drawn from J.A.R. Nafziger, The UNESCO Convention: Insights, Circumspections, and Outlooks, in: J.A. Sánchez Cordero (ed.), La Convención de la UNESCO de 1970. Sus nuevos desafíos, Universidad Nacional Autónoma de México, México 2014, p. 221.

16 See N. Palmer, Fetters and Stumbling Blocks: Impediments to the Recovery and Return of Unlawfully Removed Objects, A Common Law Perspective, in: L.V. Prott, R. Redmond-Cooper, S. Urice (eds.), Realising Cultural Heritage Law: Festschrift for Patrick O'Keefe, Institute of Art and Law, Builth Well, Crickadarn 2013.

17 Ibidem, p. 99. 
tion. ${ }^{18}$ This case is full of important procedural rulings that upheld federal seizure and forfeiture of illegally imported coins from Cyprus and China even though the "find spots" - that is, the exact geographical origins of the coins - were never proven. To be sure, Article 7(b)(i) of the 1970 UNESCO Convention limits the prohibition on importation of stolen cultural property from museums, public monuments and similar institutions to inventoried material.

A second, closely related ambiguity in the 1970 UNESCO Convention involves Article 13's recognition of the inalienability of "certain cultural property". But how certain does it have to be? Can a State claim blanket inalienability of all cultural objects that may exist within its territory or does the word "certain" limit national claims of inalienability to specifically designated material? And how mandatory is a State's declaration of inalienability? To what extent does it overcome statutes of limitation otherwise governing claims for return or restitution of material? Does inalienability deny all international transfers of ownership? Again, there would seem to be room for compromise and eventual consensus in clarifying the language.

UNESCO'S Model Provisions on State Ownership of Undiscovered Cultural Objects $2012^{19}$ forthrightly address the ambiguities in Articles 4 and 13 involving undiscovered objects. The Model Provisions were designed to be brief, accessible and intelligible. They are so broadly worded, however, that even in the light of helpful commentary, they may be difficult to enact without further elaboration or detail, let alone serve to harmonize international custom, given the statutory and judicial variations on the requirements of ownership. It may have been enough to confirm either state ownership or, alternatively, what might be called a permanent sovereignty (short of ownership) over undiscovered cultural resources so as to subject them to effective state supervision and regulation. Nevertheless, the Model Provisions do provide readily accessible, useful guidance for consideration by governments and dialogue between governments.

Yet a third ambiguity in the 1970 UNESCO Convention involves the term "museum", whose meaning has of course expanded greatly in the digital era. Also, national laws, at least in specific regulatory enactments, have otherwise expanded the meaning of the term. For example, in 1970 as well as in 1983, when the United States became a party to the 1970 Convention, the term "museum", as used in Article 7(a), was generally limited to institutions and other places of exhibition whose acquisition policies were under state control. ${ }^{20}$ Today the legal definition of a museum has expanded greatly. To cite one example from United States practice, the Na-

18 698 F. 3d 171 (2012).

19 See UNESCO, Intergovernmental Committee for Promoting the Return of Cultural Property to its Countries of Origin or its Restitution in Case of Illicit Appropriation, Seventeenth Session, 1 July 2011, CLT-2011/CONFIRMATION, 208/com.17/5; M. Frigo, Model Provisions on State Ownership of Undiscovered Cultural Objects: Introduction, "Uniform Law Review" 2011, Vol. 16, pp. 1024-1035.

20 See, e.g., Letter from William P. Rogers, United States Secretary of State, to William D. Rogers, 8 December 1970 (copy on file with the author). 


\section{COMMENTARIES}

James A.R. Nafziger

tive American Graves Protection and Repatriation Act (NAGPRA) ${ }^{21}$ defines a museum very broadly to include all public and private institutions that benefit directly or indirectly from governmental support, even if they have no exhibits or even organized collections of cultural material. For example, federally guaranteed loans to students in private universities are sufficient to characterize a private university as a "museum" whether it actually has a display or organized collection of objects.

The so-called "escape language" in the 1970 UNESCO Convention also merits attention. Is such language uniformly applied? Does it swallow up obligations? For example, Article 7(a) imposes an obligation on States Parties to take necessary measures "consistent with national legislation" to prevent museums and similar institutions from acquiring illegally exported material. Does this imply that national legislation can always trump any provisions to the contrary in the Convention? Article 8 offers another example, arguably, of escape language. It requires States Parties to "undertake" to impose penalties or administrative sanctions on irresponsible persons. Does the term "undertake" express only a vague aspiration? Or, perhaps a good faith commitment by a State Party to do something, somehow, sometime in the future? Or does the word "undertake" imply a commitment immediately to impose penalties or administrative sanctions?

\section{Strengths and weakness in practice}

Aside from such unresolved ambiguities, what are the general strengths and weaknesses of the 1970 UNESCO Convention in practice? Its main strengths include, most obviously, the obligations it imposes variously on States Parties. A less obvious strength is its menu of alternatives for international cooperation and adoption as national legislation. Still another strength is in providing a model and a vocabulary for public education concerning the importance of protecting cultural heritage and in instilling a sense of responsibility in both public and private sectors. This requirement should not be overlooked. As Prof. Janet Blake, a leading legal commentator, has observed, "[i]n many ways, the institutional and awareness-raising aspects of the 1970 Convention have been its most effective elements". ${ }^{22}$ As a result, the world takes the problem of illegal trafficking more seriously than it did before the Convention came into force. All of the principal art market countries have become parties. It is therefore no exaggeration to identify the Convention with the emergence of a new international legal order involving cultural heritage.

Despite its imperfections and ambiguities, the 1970 UNESCO Convention has unquestionably shaped laws and decisions of both States Parties and non-States

2116 November 1990, Pub. L. 101-601, 25 USC 3001-3013.

22 See J. Blake, International Cultural Heritage Law, Oxford University Press, Oxford 2015, p. 40. 
Parties. ${ }^{23}$ It has also redefined public expectations about the role of museums ${ }^{24}$ and inspired the preparation of well-respected ethical codes and guidelines. At the national level, a case in point is the adoption of the year 1970 as a uniform effective cut-off date for the acceptability of acquisitions whose provenance is insufficiently documented. ${ }^{25}$ At the institutional level, even unilateral repatriation has become more common. For example, the Denver Art Museum not only returned some 40 wooden totems, known as "vigangos", to Uganda recently, but also paid for their return. ${ }^{26}$ In the words of a prominent museum director, "I think sea change is too gentle a word [...] It's been a landslide change in collecting policy, procedure and ethics." ${ }^{27}$

On the other hand, a principal weakness of the Convention, as with so many multilateral efforts, is its reliance on good-faith implementation by States Parties and its lack of capacity for funding effective implementation, particularly by developing countries. Another problem has been a lack of national values and ethical codes to support effective cooperation. The current aggressive collecting and retention of objects in China is a case in point. ${ }^{28}$ Still another problem has been inadequate hiring and deployment of trained personnel to supervise controls over the export of cultural objects.

Many States Parties have limited or cherry-picked their obligations under the 1970 UNESCO Convention. Japan, for example, confines its treaty obligations

23 See J. Halperin, J. Pes, About-Face on Restitution, Art Newspaper, February 2014, p. 15.

24 See A. Seiff, Looted Beauty, "American Bar Association Journal" 2014, p. 32, p. 38, http://www.abajournal.com/magazine/article/how_countries_are_successfully_using_the_law_to_get_looted_cultural_treasur [accessed: 23.11.2016] ("As countries of origin grew savvier about seeking the return of their looted artworks, public opinion began shifting from seeing arts institutions as protective to unduly possessive - unfairly holding on to works to which they had no right").

25 See, e.g., S. Flescher, News and Updates: AAMD Revises Guidelines for Acquisition of Antiquities - Again, "International Foundation for Art Research Journal" 2008, Vol. 10, p. 4. For an earlier version of the 1970 cutoff provision, as found in the Code of Ethics of the Archaeological Institute of America, see J.A.R. Nafziger, R.K. Paterson, A.D. Renteln (eds.), Cultural Law: International Comparative and indigenous, Cambridge University Press, Cambridge 2010, p. 419.

26 See Sending Artworks Home, but to Whom?, "New York Times", 4 January 2014, C1, http://www.nytimes. com/2014/01/04/arts/design/denver-museum-to-return-totems-to-kenyan-museum.html?_r=0 [accessed: 22.11.2016] (quoting the museum's curator of anthropology that "just because a museum is not legally required to return cultural property does not mean it lacks an ethical obligation to do so."); see also J. Halperin, J. Pes, op. cit.

27 J. Halperin, J. Pes, op. cit. (quoting Kaywin Feldman, Director of the Minneapolis Institute of Arts).

28 See K.E. Meyer, The Chinese Want Their Art Back, "New York Times", 20 June 2015, http://www.nytimes. com/2015/06/21/opinion/the-chinese-want-their-art-back.html [accessed: 22.11.2016] An art crime expert observed as follows: "Chinese laws, on everything from theft to intellectual property, are very different from those in the West, and therefore stolen or forged artworks find a market far more easily there than abroad. A certain type of Chinese collector would be far less shy about purchasing a knowingly stolen artwork than a Western collector would. Chinese collectors could purchase stolen Chinese art and still have the pride of display, perhaps with the rationale that, whether or not the object was stolen, it should be in China, and therefore the collector was somehow aiding its liberation." 


\section{COMMENTARIES}

James A.R. Nafziger

under Article 7 to prohibiting the importation of "specifically designated" foreign cultural objects. As to the United States, I have already noted its hostility to the enforcement of foreign export controls, except as they govern the status of property expressly owned by foreign states and thereby re-characterizing illegally exported material as stolen property. Instead, three articles in the 1970 UNESCO Convention are paramount: Article $7(\mathrm{~b})$, requiring cooperation in the restitution of stolen objects to countries of origin; Article 9, enabling countries whose general or particular patrimony is in jeopardy to call upon other States Parties to prohibit the importation of pertinent objects, either unilaterally or by bilateral agreement; and Article 15, allowing if not encouraging bilateral cooperation.

Under Articles 9 and 15, bilateral agreements have been effective and increasingly comprehensive. For example, a memorandum of understanding between the United States and Greece ${ }^{29}$ restricts the importation into the United States of all archaeological material from the Upper Palaeolithic Period (beginning approximately 20,000 B.C.) through the $15^{\text {th }}$ century A.D. (C.E.) as well as ecclesiastical ethnological material representing the Byzantine culture from the 4th through the $15^{\text {th }}$ centuries A.D. The agreement also encourages the interchange of extended loans, technical assistance in cultural resource management, archaeological permits, and expansion of the registration, monitoring and enforcement capacities of both countries.

Elsewhere in the world, national models for implementing the Convention are remarkably diverse, both in the letter and in practice. ${ }^{30}$ Different margins of appreciation and administrative models nevertheless enhance global cooperation. This lack of uniformity in state practices, may reasonably be interpreted as either a weakness or perhaps a strength in the sense of more flexibility ensuring state compliance with at least those provisions that have been cherry-picked and also providing an opportunity for diverse experimentation and comparative evaluations of effectiveness. Of course, greater uniformity of commitments by States Parties and greater agreement on interpretation of ambiguous language in the 1970 Convention would help make it more effective. But complete uniformity is as unnecessary as it is impossible so long as there are stable expectations about a particular State Party's implementation of whatever commitments it has assumed, an openness of governments to expanding their commitments, and efforts by UNESCO to achieve greater uniformity, as well as a general consensus on the meaning of terms and qualifying language in the Convention. The margins of appreciation among

29 Memorandum of understanding between the government of the United States of America and the government of the Hellenic Republic concerning the imposition of import restrictions on categories of archaeological and Byzantine ecclesiastical ethnological material through the $15^{\text {th }}$ century A.D. of the Hellenic Republic, 17 July 2011. 
divergent national approaches can help guide international responses and shape the growth of a more effective regime of cultural heritage law. ${ }^{31}$

\section{National variations in export controls}

Finally, leaving aside the 1970 UNESCO Convention, it should be noted that legal systems diverge from each other on the scope and content of their export controls and other fundamentals. ${ }^{32}$ Witness, for example, the distinctive Waverley Criteria $^{33}$ followed by members of the British Commonwealth of Nations to determine whether to bar the export of cultural objects whose sale price a government is prepared to match. Legal systems also differ on the applicability of controls over privately owned material that is not a national treasure, is not of special significance, or otherwise not part of the cultural patrimony. Other differences include the definition of significance as a premise for inalienability or limited export controls, the coverage of cultural material of foreign origin, requirements of registration or not, the mechanisms of permit and licensing systems, procedures for challenge and appeal of export prohibitions, and the availability of temporary permits for loans abroad.

Although claims for the unqualified return of cultural material to countries of origin or rightful owners have met with some success in the courts, the diplomatic arena and the private sector, a trend is evident toward more collaborative solutions including long-term loans and sharing of objects. In today's troubled world, the focus of cultural heritage law and lawyers has had to shift significantly (and one might hope, only temporarily) to the deliberate devastation or dismemberment of monuments and pillage of cultural objects by terrorists and other armed rebels,

31 "[T]hose who seek to understand the interplay between international law and the cross-border recovery of art and antiquities might find it instructive to look more searchingly at the civil law operating 'on the ground': that is, in the country in which the object is located, or within the legal system before the courts of which a remedy is sought. Important cases involving the return of looted cultural objects can turn on the minutiae of the law of personal property in the particular forum. An outstanding example in England is the decision of the Court of Appeal in Government of the Islamic Republic of Iran v. Barakat Galleries Ltd [2009] QB 22, which hinged in part on a detailed examination of such arcane points as the distinction under both common law and statute between proprietary and possessory interests, the efficacy of immediate rights of possession to support claims in conversion, the effect of foreign statutes on the prior ownership of undiscovered antiquities and the proper interpretation of an elderly Court of Appeal decision involving not antiquities but (of all things) bathroom fittings. Cross-border litigants, and indeed, the drafters of cross-border instruments, should take heed of these margins of appreciation" (N. Palmer, op. cit., p. 99).

32 See Report on National Controls over the Export of Cultural Material, International Law Association, Cultural Heritage Law Committee, Report of the Seventy-fourth Conference 2010, 227, $232 \mathrm{ff}$.

33 The Waverley Criteria are posed as the following questions: Waverly one: Is the object so closely connected with our history or national life that its departure would be a misfortune?; Waverley two: Is the object of outstanding aesthetic importance?; and Waverley three: Is the object of outstanding significance for the study of some particular branch of art, learning or history? Committee on the Export of Works of Art, Etc., The Export of Works of Art Etc.: Report of the Committee Appointed by the Chancellor of the Exchequer (1952). 


\section{COMMENTARIES}

James A.R. Nafziger

often driven by iconoclastic motives and zealotry, particularly in the Middle East. Responses to such savagery have included cooperation in creating safe havens for objects and greater attention in broad anti-terrorist initiatives to the protection of cultural objects. States have also enacted specific emergency measures for the seizure and return of objects originating in zones of armed conflict and looting such as Iraq and Syria that would not otherwise be protected under the national laws of the enacting states or otherwise require the states to take any action. ${ }^{34}$

\section{Conclusions}

Overall, the tripod of GATT 1994, the 1970 UNESCO Convention against illegal trafficking, and the 1995 UNIDROIT Convention on Stolen or Illegally Exported Objects, has supported a stable platform of hard and soft instruments including EU Directive $2014 / 60$ to protect cultural heritage. These instruments have spurred an increased willingness by national legislative bodies, administrative agencies, and courts to recognize and enforce foreign export controls over designated cultural material and thereby prohibit its importation. The scope of such cooperation, however, is subject to considerable variation among states, based on constitutional, legislative, political, and other variables. Much more needs to be done to strengthen the tripod and broaden the platform it supports. The European Union initiatives, including Directive 2014/60, are in the vanguard of this effort.

\section{References}

Ancient Coin Collectors Guild v. U.S. Customs and Border Protection, 698 F. 3d 171 (2012).

Blake J., International Cultural Heritage Law, Oxford University Press, Oxford 2015.

Committee on the Export of Works of Art, Etc., The Export of Works of Art Etc.: Report of the Committee Appointed by the Chancellor of the Exchequer (1952).

Convention on the Means of Prohibiting and Preventing the Illicit Import, Export, and Transfer of Ownership of Property, 14 November 1970, 823 UNTS 231.

Council Regulation (EC) No. 116/2009 of 18 December 2008 on the export of cultural goods (codified version), OJ L 39, 10.02.2009, p. 1.

Directive 2014/60/EU of the European Parliament and of the Council of 15 May 2014 on the return of cultural objects unlawfully removed from the territory of a Member State and amending Regulation (EU) No. 1024/2012, OJ L 159, 28.05.2014, p. 1.

Final Act of the Diplomatic Conference for the Adoption of the Draft UNIDROIT Convention on the International Return of Stolen or Illegally Exported Cultural Objects, 24 June 1995, 34 ILM 1322 (1995).

34 See, e.g., United Nations Security Council Resolution No. 1483 (2003), UN Doc S/RES/1483, http:// www.unesco.org/culture/laws/pdf/resolution1483_iraq_en.pdf [accessed: 23.11.2016] (in response to the looting of the cultural heritage in Iraq). For an example of national legislation to implement the Resolution, see Miscellaneous Trade and Technical Corrections Act of 2004, Pub. L. No. 108-429, 118 Stat. 2434 para. 3002 (2004). 
Flescher S., News and Updates: AAMD Revises Guidelines for Acquisition of Antiquities - Again, "International Foundation for Art Research Journal" 2008, Vol. 10.

Frigo M., Model Provisions on State Ownership of Undiscovered Cultural Objects: Introduction, "Uniform Law Review" 2011, Vol. 16.

General Agreement on Tariffs and Trade 1994, 1867 UNTS 154, 33 ILM 1154 (1994), with reference to the original document, General Agreements on Tariffs and Trade, 30 October 1947, 55 UNTS 194.

Gerstenblith P., Models of Implementation of the 1970 UNESCO Convention: Can Their Effectiveness Be Determined?, in: L.V. Prott, P. Redmond-Cooper, S. Urics (eds.), Realising Cultural Heritage Law: Festschrift for Patrick O'Keefe, Institute of Art and Law, Builth Well, Crickadarn 2013.

Halperin J., Pes J., About-Face on Restitution, Art Newspaper, February 2014.

Letter from William P. Rogers, United States Secretary of State, to William D. Rogers, 8 December 1970 (copy on file with the author).

Memorandum of understanding between the government of the United States of Ameri$\mathrm{ca}$ and the government of the Hellenic Republic concerning the imposition of import restrictions on categories of archaeological and Byzantine ecclesiastical ethnological material through the $15^{\text {th }}$ century A.D. of the Hellenic Republic, 17 July 2011.

Meyer K.E., The Chinese Want Their Art Back, "New York Times", 20 June 2015, http://www. nytimes.com/2015/06/21/opinion/the-chinese-want-their-art-back.html [accessed: 22.11.2016].

Miscellaneous Trade and Technical Corrections Act of 2004, Pub. L. No. 108-429, 118 Stat. 2434 para. 3002 (2004).

Nafziger J.A.R., The Principles for Cooperation in the Mutual Protection and Transfer of Cultural Material, "Chicago Journal of International Law" 2007, Vol. 8.

Nafziger J.A.R., The UNESCO Convention: Insights, Circumspections, and Outlooks, in: J.A. Sánchez Cordero (ed.), La Convención de la UNESCO de 1970. Sus nuevos desafíos, Universidad Nacional Autónoma de México, México 2014.

Nafziger J.A.R., Paterson R.K., Renteln A.D. (eds.), Cultural Law: International Comparative and indigenous, Cambridge University Press, Cambridge 2010.

Native American Graves Protection and Repatriation Act, 16 November 1990, Pub. L. 101-601, 25 USC 3001-3013.

Palmer N., Fetters and Stumbling Blocks: Impediments to the Recovery and Return of Unlawfully Removed Objects, A Common Law Perspective, in: L.V. Prott, R. Redmond-Cooper, S. Urics (eds.), Realising Cultural Heritage Law: Festschrift for Patrick O'Keefe, Institute of Art and Law, Builth Well, Crickadarn 2013.

Pobric P., US Fails to Tackle Art Crime, "Art Newspaper", April 2013.

Principles for Cooperation in the Mutual Protection and Transfer of Cultural Material, International Law Association, Report of the Seventy-Second Conference 2006.

Prott L.V., UNESCO International Framework for the Protection of the Cultural Heritage, in: J.A.R. Nafziger, A.M. Nicgorski (eds.), Cultural Heritage Issues: The Legacy of Conquest, Colonization and Commerce, Martinus Nijhoff Publishers, Leiden 2009.

Report on National Controls over the Export of Cultural Material, International Law Association, Cultural Heritage Law Committee, Report of the Seventy-fourth Conference 2010. 


\section{COMMENTARIES}

James A.R. Nafziger

Seiff A., Looted Beauty, "American Bar Association Journal" 2014, http://www.abajournal. $\mathrm{com} / \mathrm{magazine} /$ article/how_countries_are_successfully_using_the_law_to_get_looted_cultural_treasur [accessed: 23.11.2016].

Sending Artworks Home, but to Whom?, "New York Times", 4 January 2014, C1, http://www. nytimes.com/2014/01/04/arts/design/denver-museum-to-return-totems-to-kenyan-museum.html?_r=0 [accessed: 22.11.2016].

Treaty on the Functioning of the European Union (consolidated version), OJ C 326, 26.10.2012, p. 47.

UNESCO Convention on the Protection and Promotion of the Diversity of Cultural Expressions, 20 October 2005, 2440 UNTS 311.

UNESCO Convention on the Protection of the Underwater Cultural Heritage, 2 November 2001, 41 ILM 37 (2002).

UNESCO, Intergovernmental Committee for Promoting the Return of Cultural Property to its Countries of Origin or its Restitution in Case of Illicit Appropriation, Seventeenth Session, 1 July 2011, CLT-2011/CONFIRMATION, 208/com.17/5.

United Nations Security Council Resolution No. 1483 (2003), UN Doc S/RES/1483, http://www.unesco.org/culture/laws/pdf/resolution1483_iraq_en.pdf [accessed: 23.11.2016].

Voon T., Cultural Products and the World Trade Organization, Cambridge University Press, Cambridge 2007.

Vrdoljak A.F., International Law, Museums and the Return of Cultural Objects, Cambridge University Press, Cambridge 2006.

Wilcox C., A Charter for World Trade, Macmillan, New York 1949. 